\title{
Histopathological evaluation and parasite quantification (qPCR) in the male dog's genital system after natural infection with Leishmania infantum
}

\author{
Avaliação histopatológica e quantificação parasitária (qPCR) no sistema \\ genital de cães machos após infecção natural com Leishmania infantum
}

\author{
Vinícius Vasconcelos Gomes de Oliveira ${ }^{I^{*}, \text { IV }}$ Simone Regina Barros de Macedo \\ Flábio Ribeiro de Araújo" Carlos Alberto do Nascimento Ramos ${ }^{\text {II }}$ \\ Rafael Antonio Nascimento Ramos ${ }^{\text {III }}$ Frederico Celso Lyra Maia ${ }^{\text {III }}$ \\ Leucio Câmara Alves ${ }^{\text {III }}$ Valdemiro Amaro da Silva Junior ${ }^{\text {III }}$
}

ABSTRACT

Canine visceral leishmaniasisis an important disease caused by the protozoon Leishmania infantum which affects several organs and systems, including the genital tract. The L. infantum tropism to the male genital system and correlation among parasite load, immunohistochemistry detection and structural changes in these organs is controversy. Therefore, the aim of this study was to evaluate this correlation in the genital organs of the male dogs naturally infected with $\mathbf{L}$. infantum. Samples from testicles, epididymis, prostate, glans penis, prepuce and scrotum were collected from 19 positive adult dogs. Structural changes were observed in the testicles (5.2\%), epididymis $(2.6 \%)$, prepuce $(5.2 \%)$ and scrotum (5.2\%) of the samples positive at immunohistochemistry examination. Conversely, similar structural changes were observed in all tissues negative at immunohistochemistry analysis. Moreover, L. infantum DNA was detected in all organs with the highest parasite load found in testicles, epididymis, and prostate gland. , Testicles had the highest parasite load but the lowest number of inflammatory lesions. These inflammatory lesions were observed in all organs of reproductive system of dogs; however, no correlation was observed between the parasite load and inflammatory lesions of dogs naturally infected with $\mathbf{L}$. infantum.

Key words: canine visceral leishmaniasis, structural changes, genital pathology, immunohistochemistry.

\section{RESUMO}

A Leishmaniose Visceral Canina é uma importante enfermidade causada pelo protozoário Leishmania infantum que afeta diversos órgãos e sistemas, incluindo o trato genital. No entanto, o tropismo da $\boldsymbol{L}$. infantum pelo sistema genital masculino e a correlação entre carga parasitária, detecção imunohistoquímica e alterações estruturais nesses órgãos ainda é uma questão controversa. Sendo assim, o objetivo deste estudo foi avaliar essa correlação em órgãos genitais de cães naturalmente infectados por $\boldsymbol{L}$. infantum. Para tal, amostras de testículos, epidídimos, próstata, glande, prepúcio e escroto foram coletadas de 19 cães adultos positivos. Lesões microscópicas associadas com imunomarcação de formas amastigotas do parasito foram observadas nos testículos (5,2\%), epidídimos (2,6\%), prepúcio $(5,2 \%)$ e escroto (5,2\%). Por outro lado, alterações estruturais sem imunomarcação foram observadas em todos os órgãos. Além disso, o DNA de L. infantum foi encontrado em todos os órgãos com maior carga parasitária nos testículos, epidídimos e próstata. Curiosamente, os testículos apresentaram a maior carga parasitária, porém apresentaram o menor grau de lesões inflamatórias. Essas lesões inflamatórias foram observadas em todos os órgãos do sistema reprodutor de cães com L. infantum. Entretanto, não houve correlação entre carga parasitária e lesões inflamatórias nestes órgãos.

Palavras-chave: leishmaniose visceral canina, alterações estruturais, patologia genital, imunohistoquímica.

\section{INTRODUCTION}

In Brazil, canine visceral leishmaniasis (CVL) is an important zoonosis caused by $\mathbf{L}$. infantum, and dogs are the main reservoirs in urban areas (COSTA, 2008). This disease is traditionally endemic in the Brazilian northeast region,being detected several cases in the state of Pernambuco (COSTA, 2008).

\footnotetext{
'Departamento de Morfologia e Fisiologia Animal, Universidade Federal Rural de Pernambuco (UFRPE), Rua Dom Manoel de Medeiros, s/n, Dois Irmãos, 52171-900, Recife, PE, Brasil. E-mail: vinicius-vasconcelos@hotmail.com. *Corresponding author.

I'Área de Saúde Animal, Embrapa Gado de Corte, Campo Grande, MS, Brasil.

IIIDepartamento de Medicina Veterinária, Universidade Federal Rural de Pernambuco (UFRPE), Recife, PE, Brasil.

${ }^{\text {IV }}$ Centro Acadêmico de Vitória, Universidade Federal de Pernambuco (UFPE), Vitória de Santo Antão, PE, Brasil. Received 06.12.15 Approved 08.26.15 Returned by the author 12.08.15 CR-2015-0850.R3
} 
CVL is primarily transmitted to mammals by sand flies; although, cases of direct transmission between dogs, such as transplacentary and venereal transmission have already been reported (SILVA et al., 2009; NAUCKE \& LORENTZ, 2012). Studies of direct transmission are pivotal to better understand the epidemiology of the disease and clarify some aspects such as the maintenance of the parasite in an area where vectors are absent.

It is known that male positive dogs may develop chronic inflammatory lesions in the testicles, epididymis, prostate, glans penis and prepuce (DINIZ et al., 2005; MANNA et al., 2012;MIR et al., 2012). In addition, amastigote forms of $\boldsymbol{L}$. infantum may be detected in the semen favoring the occurrence of sexual transmission (DINIZ et al., 2005).

However, the tropism of $\boldsymbol{L}$. infantum for the male genital organs and the correlation between the parasite load and structural changes has not been studied. Therefore, the aim of this study was to evaluate the correlation among structural changes, detection of amastigote forms by immunohistochemistry (IHC) and parasite load by qPCR in the genital organs of male dogs naturally infected with $L$. infantum.

\section{MATERIALS AND METHODS}

Animals and biological samples.

All animals were provided by the Zoonotic Disease Control Center from Petrolina, state of Pernambuco, Brazil (Latitude 09 23' 55"; Longitude $40^{\circ} 30^{\prime} 03$ "). The $\boldsymbol{L}$. infantum infection was confirmed by indirect fluorescent antibody test (IFAT $\geq 40$ ), parasitological bone marrow examination, immunohistochemistry (IHC) and real-time PCR of the fragments of liver, spleen, lymph nodes and skin.

Nineteen male stray dogs positive for $\boldsymbol{L}$. infantum were submitted to euthanasia procedures by Zoonotic Disease Control Center according to the Health Brazilian Ministry recommendations. After euthanasia, fragments of testicles, epididymis, prostate, glans penis, prepuce and scrotum were collected. All of them were evaluated by histopathology, IHC and qPCR.

Histopathological evaluation.

Samples were fixed with $10 \%$ neutral buffered formalin for 48 hours and routinely processed to paraffin embedding. Sections $(5 \mu \mathrm{m})$ were mounted onto slides and stained with hematoxylin and eosin (HE) (TOLOSA et al., 2003). All tissues were evaluated according to inflammatory infiltrates type, intensity of the inflammatory reactions $(0=$ absent; $1=$ mild; $2=$ moderate; and $3=$ intense) and structural damage.

Immunohistochemistry.

The detection of amastigote forms of $\boldsymbol{L}$. infantum was carried out following the method described by TAFURI et al. (2004). A heterologous hyperimmune serum of one dog naturally infected with $\boldsymbol{L}$. infantum (positive at parasitological examination of bone marrow and immunofluorescent assay - title $\geq 1: 40$ ), diluted at 1:100 (0.01 M PBS), was used as primary antibody. A commercially available streptavidinperoxidase complex (LSAB+ kit, Dako USA) was employed as detection system. The reactions were revealed by diaminobenzidine (DAB) and the slides counter-stained with hematoxylin. The IHC was scored according to the number of amastigotes observed under a high magnification microscopic field ( $0=$ no amastigotes; $1=1-3$ amastigotes; $2=4$ 10 amastigotes; $3=>10$ amastigotes).

\section{Molecular diagnosis}

Genomic DNA from all samples collected and from an in vitro culture of $\boldsymbol{L}$. infantum were extracted using the DNeasy BLOOD \&TISSUE Kit (Qiagen ${ }^{\circledR}$ Hilden-Germany) according to the manufacturer's instructions. Subsequently, DNA concentrations were determined by means of spectrophotometry in the GeneQuant ${ }^{\circledR}$ RNA/ DNA calculator (GE Healthcare Bio-Sciences Corp.; New Jersey, USA). The integrity of the DNA samples was evaluated by means of electrophoresis on $0.8 \%$ agarose gel, stained with ethidium bromide $\left(0.5 \mu \mathrm{gml}^{-1}\right)$. All the procedures were performed using micropipette barrier tips to prevent contamination.

The qPCR reaction for the detection of $\boldsymbol{L}$. infantum $\mathrm{DNA}$ was performed using primers Leish-1 [5 '-AACTTTTCTGGTCCTCCGGGTAG-3'] and Leish-2 [5'-ACCCCCAGTTTCCCGCC-3'] and the TaqMan MGB-probe [FAM-5'AAAAATGGGTGCAGAAAT-3' non-fluorescent quencher-MGB], as described by FRANCINO et al. (2006). The qPCR was performed in a CFX96 ${ }^{\mathrm{TM}}$ Real-Time System (Bio-Rad Laboratories, Inc., Hercules CA, USA). The reaction mixture $(12.5 \mu \mathrm{L})$ contained $6.25 \mu \mathrm{L}$ of Taqman $^{\circledR}$ Universal PCR Master Mix, each primer at a concentration of $900 \mathrm{nM}$, probe at a concentration of $200 \mathrm{nM}$ and $1 \mu \mathrm{L}$ of template DNA.

The run consisted of a hot start at $95^{\circ} \mathrm{C}$ for 3 minutes and 42 cycles of denaturation $\left(95^{\circ} \mathrm{C}\right.$ for 
10 seconds) and annealing-extension $\left(60^{\circ} \mathrm{C}\right.$ for 30 seconds). All assays were carried out in duplicate, with a negative control (DNA of a dog from a nonendemic area) and a positive control (DNA from an in vitro culture of $\boldsymbol{L}$. infantum) included in each run.

The parasite load was determined by the absolute quantification method. A standard curve was constructed using DNA extracted from serial dilutions of a $\boldsymbol{L}$. infantum cultures containing approximately $5.6 \times 10^{6}$ parasites $\mathrm{ml}^{-1}$. Considering an extraction efficiency of $100 \%$, five points were used to construct the curve $(0.1,1,10,1000$ and 1,000,000 parasites $\mathrm{ml}^{-1}$ of culture). Considering that the DNA extraction was performed using $300 \mu \mathrm{L}$ of $\mathbf{L}$. infantum culture, the final product of the extractions were diluted in a final volume of $100 \mu \mathrm{L}$, and $1 \mu \mathrm{L}$ of DNA was used per reaction, the points cited above correspond to $0.0003,0.003$, $0.03,3$ and 3000 parasites, respectively. Therefore, based on the same principle, and considering that DNA extractions of tissues were performed using $25 \mathrm{mg}$ of each sample, our results were expressed as number of parasites $250 \mu \mathrm{g}^{-1}$ of tissue.

\section{Statistical analyses}

The parasite load determined by qPCR, the number of amastigotes detected by IHC and the inflammatory score after HE staining were compared using the Kruskal-Wallis test. A correlation analysis between these values was performed through the Spearman correlation. For comparisons of diagnostic techniques was used Fisher's exact test. All analyses were performed using R software version 2.15.2 (R Core Team, 2012). To test the Spearman values, the qPCR data (parasites $250 \mu \mathrm{g}^{-1}$ of tissue) were transformed into scores according to the following criteria: $0=0$; $0.001-0.01=1 ;>0.01-0.1=2 ;>0.1-1=3 ;>1-2=4$; $>2-5=5 ;>5-6=6 ;>6-7=7 ; \ldots ;>100=100$.

\section{RESULTS}

The male genital organs showed chronic inflammatory lesions that ranged from mild to moderate or severe. These lesions presented lymphocytes, plasma cells and macrophages (Figures 1A-1F, Table 1).

Amastigote forms of $\boldsymbol{L}$. infantum were detected by IHC in the interstitial compartment of testicles, epididymis and connective tissue of prepuce and scrotum (Table 1; Figures 1G-1I). However, none amastigote form of $\boldsymbol{L}$. infantum was detected in the prostate or glans penis (Table 1).
DNA of $\boldsymbol{L}$. infantum was detected in at least one of the organs in $94.7 \%(18 / 19)$ of animals (Table 1). The results showed that the parasite load was low in all animals, except for dogs 16 and 17 . These animals (i.e., dogs 16 and 17) presented high parasite loads in the testicles, epididymis, prepuce and scrotum (Table 2). Significant difference was observed between the parasite load determined by $\mathrm{qPCR} \quad(\mathrm{P}=0.0197)$ and inflammatory grade $(\mathrm{P}=0.0100)$. However, no difference was detected when they were evaluated by IHC $(\mathrm{P}=0.8414)$.

The parasite load was higher in the testicles and epididymis, although there were no difference for the values observed in the prostate and glans penis. Testicles had the lowest score related to inflammatory lesions but no difference was observed between testicles, epididymis and glans penis. No significant difference was detected for the samples evaluated by IHC (Table 1).

The Spearman correlation test did not detect significant correlation between parasite load and inflammatory score to the testicles $(\mathrm{P}=0.346)$, epididymis $(\mathrm{P}=0.259)$, prostate $(\mathrm{P}=0.799)$, glans $(\mathrm{P}=0.260)$, prepuce $(\mathrm{P}=0.234)$ and scrotum $(\mathrm{P}=0.166)$. In this study, Fisher's exact test $(\mathrm{P}<0.001)$ indicated that the qPCR method was more efficient than the IHC method in the detection of amastigote forms in the infected tissues.

\section{DISCUSSION}

In CVL, chronic inflammatory lesions were observed in the testicular intertubular region (DINIZ et al., 2005). In this study, testicular inflammatory lesions were observed in 26.3\% (10/38) of the testicles evaluated. According to MANNA et al. (2012), the $\boldsymbol{L}$. infantum amastigotes triggered the inflammatory response in the testicles. Experimental infections of hamsters with Leishmania donovani triggered testicular amyloidosis, degeneration, progressive atrophy and azoospermia. In the same experimental model, degenerative changes have been also associated with lymphocytes infiltration and macrophages containing amastigotes in the testicles (GONZALEZ et al., 1983). In the present experiment, the $\boldsymbol{L}$. infantum amastigotes were not detected in the seminiferous tubules lumen and germinative epithelium corroborating with the findings previously described by DINIZ et al. (2005).

The qPCR results reported that the testicular tissue presented the highest parasite load. MANNA et al. (2012) also observed a high parasite load in the testicular tissue using the same 




diagnostic method. Although the testicles used in the present study had showed a higher parasite load, no correlation with the intensity of the inflammatory changes was observed. These inflammatory reactions occurred in the testicular tissue with lower intensity when compared to other male genital organs. Thus, this study demonstrated that the parasite load in the testicle was not related to the severity of inflammatory lesions, differently from previous reports (MANNA et al., 2012). Moreover, according to our research, the high parasite load and chronic infiltrated does not guarantee that amastigotes will be detected by IHC. Similar data have been reported by XAVIER et al. (2006).
Our data of inflammatory reaction in the epididymis are similar to those reported by DINIZ et al. (2005) that described the same structural change in this organ of dogs with CVL. The presence of lymphocytes between the epithelial cells of the epididymal duct may increase the possibility that L. infantum amastigotes migrate into the seminal fluid. Epididymitis is frequently associated with inflammatory cells in the semen of these animals (NELSON \& COUTO, 1994) and could be related to venereal transmission of CVL (SILVA et al., 2009; NAUCKE \&LORENTZ, 2012).

Our findings related to the prostate do not corroborate with DINIZ et al. (2005) that showed

Ciência Rural, v.46, n.4, abr, 2016. 
Table 1 - Absolute and relative values of the histopathological lesions (HE), IHC to amastigotes, qPCR positivity and comparisons between mean ranks for each organ evaluated in the male dog's genital system after natural infection with $L$. infantum.

\begin{tabular}{|c|c|c|c|c|c|}
\hline \multirow{2}{*}{ Organ } & \multicolumn{3}{|c|}{ 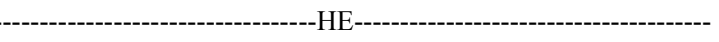 } & \multirow[t]{2}{*}{$\mathrm{IHC}$} & \multirow[t]{2}{*}{ qPCR } \\
\hline & Mild & Moderate & Severe & & \\
\hline Epididymis $(\mathrm{n}=38)$ & $14(36.8 \%)$ & $6(15.8 \%)$ & $6(15.8 \%)$ & $1(2.6 \%)$ & $16(84.2 \%)$ \\
\hline Scrotum $(n=19)$ & $8(42.1 \%)$ & $7(36.8 \%)$ & $1(5.2 \%)$ & $1(5.2 \%)$ & $7(36.8 \%)$ \\
\hline Glans $(\mathrm{n}=19)$ & $8(42.1 \%)$ & $7(36.8 \%)$ & 0 & 0 & $15(78.9 \%)$ \\
\hline Prepuce $(n=19)$ & $5(26.3 \%)$ & $9(47.3 \%)$ & $3(15.8 \%)$ & $1(5.2 \%)$ & $9(47.4 \%)$ \\
\hline Prostate $(n=19)$ & $4(21.0 \%)$ & $10(52.6 \%)$ & $2(10.5 \%)$ & 0 & $15(78.9 \%)$ \\
\hline Testicles $(\mathrm{n}=38)$ & $2(5.2 \%)$ & $2(5.2 \%)$ & $6(15.8 \%)$ & $2(5.2 \%)$ & $17(89.5 \%)$ \\
\hline Organs & \multicolumn{3}{|c|}{ qPCR } & \multicolumn{2}{|r|}{$\mathrm{HE}$} \\
\hline Epididymis & \multicolumn{2}{|c|}{$67.03 \mathrm{a}$} & $58.47 \mathrm{a}$ & \multicolumn{2}{|r|}{$53.66 \mathrm{ab}$} \\
\hline Scrotum & \multicolumn{2}{|c|}{$38.95 \mathrm{c}$} & $58.58 \mathrm{a}$ & \multicolumn{2}{|r|}{$59.89 \mathrm{a}$} \\
\hline Glans & \multicolumn{2}{|c|}{$64.37 \mathrm{ab}$} & $55.50 \mathrm{a}$ & \multicolumn{2}{|r|}{$55.05 \mathrm{ab}$} \\
\hline Prepuce & \multicolumn{2}{|c|}{$45.71 \mathrm{bc}$} & $58.47 \mathrm{a}$ & \multicolumn{2}{|r|}{$71.55 \mathrm{a}$} \\
\hline Prostate & \multicolumn{2}{|c|}{$60.55 \mathrm{ab}$} & $55.50 \mathrm{a}$ & \multicolumn{2}{|r|}{$68.55 \mathrm{a}$} \\
\hline Testicles & \multicolumn{2}{|c|}{$68.39 \mathrm{a}$} & $58.47 \mathrm{a}$ & \multicolumn{2}{|r|}{$36.29 \mathrm{~b}$} \\
\hline
\end{tabular}

Means followed by the same letter in the column do not differ significantly $(\mathrm{P}>0.05)$.

a very low frequency of inflammatory changes in this organ. However, MIR et al. (2012) have also reported prostatitis in infected dogs, and their results are in agreement with the results reported in the present study.

In the glans penis and prepuce, the histopathological findings were similar to those obtained in a study by DINIZ et al. (2005) that described a histio-plasmo-lymphocytic inflammatory reaction. The high frequency of inflammation associated with the presence of L. infantum amastigotes in the glans penis and prepuce may also contribute to the presence of the parasite in the semen (DINIZ et al., 2005), increasing the chances of venereal transmission (SILVAet al., 2009; NAUCKE \&LORENTZ, 2012). Conversely, the parasite load and immunostaining intensity to $\boldsymbol{L}$. infantum amastigote were not directly correlated with the chronic inflammatory reaction observed in the connective tissue of the structures mentioned above.

In the scrotum, the chronic inflammatory reaction was similar to that observed in other cutaneous areas in animals with CVL (SOLANOGALLEGO et al., 2009). However, the significance of the macrophages filled with melanin next to the inflammatory infiltrate were not clarified because no relationship between inflammatory factors and melanogenesis has been described for dogs naturally infected with $L$. infantum. Conversely, hyperpigmentation is a clinical sign commonly observed in humans (NEGHINA et al., 2009).

The detection of positive animals to $\boldsymbol{L}$. infantum in vector-free areas indicates to additional forms of transmission. The lesions observed on the glans penis, prepuce and testicle in this research, as well as DNA detection in the semen of positive dogs (DINIZ et al., 2005), raises the strong suspicion that venereal transmission may occurs.

The difference of detection by IHC and qPCR can be related with the low parasite load observed in each organ. It is believed that in these organs the parasites may be restricted to the blood. This hypothesis is relevant, since this biological sample (i.e., blood) was considered suitable for DNA detection by PCR in suspected cases of CVL (LACHAUD et al., 2002).

\section{CONCLUSION}

CVL is associated with a high incidence of the chronic inflammatory lesions in the male genital organs. However, the detection of $\boldsymbol{L}$. infantum DNA in the genital male organs as well as the lack of relationship between the parasite load and chronic inflammatory lesions indicated that the number of parasites is not related with the level of inflammatory reaction in the tissues evaluated. In addition, these lesions may contribute to the presence of the parasite in the semen, which favor the occurrence of venereal transmission. 
Table 2 - Parasite load of each biological sample from dogs naturally infected by $\boldsymbol{L}$. infantum.

\begin{tabular}{|c|c|c|c|c|c|c|}
\hline Animal & Testicles & Epididymis & Prostate & Glans & Prepuce & Scrotum \\
\hline A1 & 0.052 & 0.068 & 0.341 & 0 & 0 & 0 \\
\hline $\mathrm{A} 2$ & 0 & 0 & 0 & 0 & 0 & 0 \\
\hline $\mathrm{A} 3$ & 0.361 & 0.359 & 0.138 & 0.097 & 0.237 & 0 \\
\hline A4 & 0.194 & 0.084 & 0.643 & 0.422 & 0.003 & 0 \\
\hline A5 & 0 & 0.127 & 0.235 & 0.127 & 0 & 0.004 \\
\hline A6 & 0.684 & 0.107 & 0.104 & 5.195 & 1.509 & 2.171 \\
\hline A7 & 0.239 & 0.36 & 0.133 & 0.11 & 0.038 & 0.531 \\
\hline A8 & 0.088 & 0 & 0.01 & 0.096 & 0 & 0 \\
\hline A9 & 0.063 & 0.015 & 0.26 & 0.109 & 0 & 0 \\
\hline A10 & 0.047 & 0.143 & 0.034 & 0.039 & 0.141 & 0.04 \\
\hline A11 & 0.081 & 0 & 0 & 0.034 & 0 & 0.095 \\
\hline $\mathrm{A} 12$ & 0.068 & 2.712 & 0.789 & 0.05 & 0.015 & 0 \\
\hline $\mathrm{A} 13$ & 0.314 & 0.108 & 0 & 56.731 & 0 & 0 \\
\hline A14 & 0.19 & 0.202 & 0.17 & 0.333 & 0 & 0 \\
\hline A 15 & 0.132 & 0.051 & 2.353 & 0 & 0 & 0 \\
\hline A16 & $41,424.992$ & $1,044.656$ & 1.002 & $102,456.297$ & $21,817.971$ & 1.811 \\
\hline A17 & 32.566 & $4,278.534$ & 0.149 & 86.883 & 36.446 & 29.809 \\
\hline A18 & 0.247 & 2.105 & 0.033 & 0 & 0 & 0 \\
\hline A19 & 6.113 & 19.67 & 0 & 354.913 & $3,567.594$ & 0 \\
\hline
\end{tabular}

Results expressed as number of parasite $250 \mu \mathrm{g}^{-1}$ of tissue.

\section{ACKNOWLEDGMENTS}

Authors thank the staff of the Zoonotic Disease Control Center of the Municipality of Petrolina, particularly the veterinarian Michelle Pascoal.

\section{BIOETHICS \\ AND \\ COMMITTE APPROVAL}

BIOSSECURITY

The present study was approved by the Ethics Committee for Animal Experimentation of the Universidade Federal Rural de Pernambuco (UFRPE) (protocol ECAE: 23082.015186/2012).

\section{REFERENCES}

COSTA, C.H.N. Characterization and speculations on the urbanization of visceral Leishmaniasis in Brazil. Cadernos de Saúde Pública, v.24, n.12, p.2959-2963, 2008. Available from: <http://www.scielo.br/scielo.php?pid=S0102$311 \times 2008001200027 \& \mathrm{script}=\mathrm{sci}$ arttext $>$. Accessed Feb. 04, 2015. doi: 10.1590/S0102-311X2008001200027.

DINIZ, S.A. et al.Genital lesions associated with visceral leishmaniasis and shedding of Leishmania sp. in the semen of naturally infected dogs. Veterinary Pathology, v.42, n.5, p.650-658, 2005. Available from: <http://vet.sagepub.com/ content/42/5/650.full.pdf $>$. Accessed: Aug. 13, 2014. doi: $10.1354 /$ vp.42-5-650.

FRANCINO,O. et al. Advantages of real-time PCR assay for diagnosis and monitoring of canine leishmaniosis.
Veterinary Parasitology, v.137, p.214-221, 2006. Available from: <http://www.ncbi.nlm.nih.gov/pubmed/16473467>. Accessed: Feb. 04, 2015. doi: 10.1016/j.vetpar.2006.01.011.

GONZALEZ,J.L. et al. Testicular amyloidosis in hamsters experimentally infected with Leishmania donovani. British Journal of Experimental Pathology, v.64, p.518-523, 1983.

LACHAUD, L. et al. Comparison of six PCR methods using peripheral blood for detection of canine visceral leishmaniasis. Journal of Clinical Microbiology, v.40, n.1, p.210-215, 2002 .

MANNA, L. et al. Detection of Leishmania parasites in the testis of a dog affected by orchitis: case report. Parasites $\boldsymbol{\&}$ Vectors, v.5, p.1-4, 2012. Available from: <http://www. parasitesandvectors.com/content/5/1/216>. Accessed: Feb. 04, 2015. doi:10.1186/1756-3305-5-216.

MIR, F. et al. Subclinical leishmaniasis associated with infertility and chronic prostatitis in a dog. Journal of Small Animal Practice, v.53, p.419-422, 2012. Available from: $<$ http://www.ncbi.nlm.nih.gov/pubmed/22690941>. Accessed: Aug. 12, 2014. doi: 10.1111/j.1748-5827.2012.01224.x.

NAUCKE, T.J.; LORENTZ, S. First report of venereal and vertical transmission of canine leishmaniosis from naturally infected dogs in Germany. Parasites \& Vectors, v.5, p.67, 2012. Available from: $<$ http://www.parasitesandvectors.com/content/5/1/67>. Accessed: Aug. 12, 2014.doi: 10.1186/1756-3305-5-67.

NEGHINA, R. et al. Importation of visceral leishmaniasis in returning Romanian workers from Spain. Travel Medicine and Infectious Disease, v.7, p.35-39, 2009.

Ciência Rural, v.46, n.4, abr, 2016. 
NELSON, R.W., COUTO,C.G. Fundamentos de medicina interna de pequenos animais. Rio de Janeiro: Guanabara Koogan, 1994. 737p.

R CORE TEAM. R: a language and environment for statistical computing. Vienna: R Foundation for Statistical Computing, 2012. Available from: <http://www.R-project. org/>. Accessed: Nov. 22, 2012.

SILVA, F.L. et al. Venereal transmission of canine visceral leishmaniasis. Veterinary Parasitology, v.160, p.55-59, 2009. Available from: <http://www.sciencedirect.com/ science/article/pii/S0304401708006031>. Accessed: Aug. 10, 2014. doi: 10.1016/j.vetpar.2008.10.079.

SOLANO-GALLEGO, L. et al.Directions for the diagnosis, clinical staging, treatment and prevention of canine leishmaniosis. Veterinary Parasitology, v.165, p.1-18, 2009.
TAFURI, W.L. et al. An alternative immunohistochemical method for detecting Leishmania amastigotes in paraffinembedded canine tissues. Journal of Immunological Methods, v.292, n.1-2, p.17-23, 2004.

TOLOSA,E.M.C. et al. Manual de técnicas histológicas normal e patológica. São Paulo: Manole, 2003. 331p.

XAVIER,S.C. et al. Comparison of paraffin-embedded skin biopsies from different anatomical regions as sampling methods for detection of Leishmania infection in dogs using histological, immunohistochemical and PCR methods. BMC Veterinary Research, v.2, p.1-7, 2006. Available from: <http://www. biomedcentral.com/1746-6148/2/17>. Accessed: Feb. 04, 2015. doi: 10.1186/1746-6148-2-17. 